\title{
Some Conceptual and Empirical Perspectives on Economic Growth and Development in South Asia, with Special Reference to India
}

\author{
Waqif $A^{*}$ \\ Jawaharlal Nehru Technological University, India
}

*Corresponding author: Airf Waqif, Jawaharlal Nehru Technological University, India,

Email: waqif.arif@gmail.com

\section{Mini Review}

Volume 2 Issue 1

Received Date: March 02, 2018

Published Date: April 03, 2018

DOI: $10.23880 /$ phoa- 16000119

\section{Abstract}

Increasingly economic policies in both developing and developed during the last few decades of Liberalistion, Privatisation and Globalisation (LPG) have been focussing on achieving higher economic (GDP) growth rates. Such growth rates bring relatively more developmental benefits to middle and upper income groups. But they do not necessarily and automatically equally benefit those at the lower end of the socio-economic pyramid. They may even contribute to high discontent among such groups, possibly resulting in the disruption of LPG-led economic and development policies.

Keywords: Empirical perspectives; Economic growth; Social pyramid; Economic policy; India

Abbreviations: GDP: Gross Domestic Product; LPG: Liberalistion Privatisation and Globalisation.

\section{Introduction}

There has been increasing emphasis and need in economic policy, especially in developing countries, to promote higher rates of economic growth that is Gross Domestic Product (GDP).., in an increasingly globalised environment. Many developing countries like China, India, among others, have evinced high economic growth rates in the last few decades. Many other economic commentators, including Nobel Laureat Joseph Stiglitz (see, e.g, Stiglitz 2002/2003) have questioned such "Growth Fetishism.." Stiglitz persuasively argues that such growth has not benefited even the US economy by bringing about more inclusive and equitable development. Many other analysts have similarly expressed doubts about pursuit of unfettered economic growth and its impact on more wide-spread development, especially of those at the bottom of the economic and social pyramid. Whom does such growth primarily benefit? [1,2].

\section{Composition of Recent Economic Growth: In Developing countries like India}

During the last more than two decades, since 1991 India increasingly liberalised and globalised its economy. This economic policy led to much higher GDP growth compared to the previous decades.

But evidence suggests that such growth has been primarily in what economists refer to as "while goods and services" higher availability of private transport, electrical and mechanical household appliances, packaged and branded foods and clothing through global/local department stores and malls, privatised educational and health care institutions, privatised tourism and travel, among other such areas.

But there has not been commensurate growth in "wage goods and services" - publically organised affordable and effective access to minimum food and nutrition, public urban and rural transport, public education and health care services, and more generally and importantly, to government services and welfare programmes, .especially 
for the relatively disadvantaged communities.

\section{Driving Factors}

Such economic growth more in favour of the middle and upper income groups in developing countries like India has been primarily driven by the influence of such groups on domestic economic policies, and the unavoidable compulsions of the global economy in general and global private and multi-lateral financial institutions in particular. Organisations and institutions which promote the welfare of those at the lower end of the economic and social pyramid e.g. trade unions,, grass roots, voluntary and non-governmental organisations, farmers' organisations, among many such others have been increasingly sidelined in economic policy making processes.

\section{Economic and Social Consequences in Developing Countries}

Relative lack of suitable employment and income generating opportunities in countries like in India has resulted in wide-spread emigration of both skilled and semi-skilled workers to "greener pastures." in the Middle East, US, UK, Australia, among others. A study in UK in the mid 1990s, e.g. Estimated that emigration of skilled Indians to the US during 1985-95 amounted to "reverse foreign aid by India of about US \$s 20 billion to the US." This being the estimated amount the US would have to spend to train its own citizens in comparable skills.

Because of such flight of workers from India ("Quit India") there is relative shortage of qualified faculty in academic institutions on the one hand, and similar shortage of semi-skilled workers like plumbers, electricians etc, on the other..Even in Indian villages, families have some relative working abroad who sends remittances.

Such inflows of remittances have no doubt befitted the local relatives of the emigrants. They have also contributed to higher real estate prices and rents but also to higher costs of education and health care for the common person.

One such example of "exclusivity" is the promotion of "medical tourism" in India. Foreign patients with foreign currencies are increasingly offered "five star" medical and hospital facilities in private/corporate hospitals, crowding out less cash-rich locals from such facilities.. A cartoon telling depicted that a security guard at a private hospital asked a potential patient, "Are you an Non Resident Indian?
Do you have international medical insurance? If not, go to a government hospital."

\section{Illustrative Data on South Asia and India}

- Gross National Per Capita Income ppp \$s in South Asia (8 countries)

1962: 85.9; 2016: 1,616 (X 18.7)

- India's GNI per capita in PPP \$s : 1995 : 1,470; 2016 : 6,490 (X 4.4)

- India's poverty ratio at ppp \$ 1.9 per day, $2011: 21.23$ per cent, or 255 million persons

- India' unemployment 2010: 9.4 per cent, or 48.3 million persons

Source: World Bank Data Bases

For broader conceptual and empirical perspectives in South Asia, see also Waqif, 1994 [3,4].

\section{Possible Scenarios (a la Albert Hirschman, 1973)}

When disproportionately large numbers of people are unemployed and/or poor, they are likely to, in the following order:

- Resort to peaceful street demonstrations and protests.

- Represent to concerned political and administrative authorities.

- Resort to strikes and shutdowns wherever possible.

- Undertake illegal and violent means to redress their grievances, including.

- Increasing criminal activities.

- Sabotaging the normal economic and developmental processes.

- Unorganised and organised violent protests.

\section{References}

1. Albert OH, Michael R (1973) The Changing Tolerance for Income Inequality in the Course of Economic Development. Quarterly Journal of Economics 87(4): 544-566.

2. Joseph ES (2002) Globalisation and its Discontents, WW Norton \& Company. New York/Penguin Books, India.

3. Waqif Arif A (1994) Employment Generation and Poverty Alleviation in South Asia, Perspectives and Scenario, Coordinating Group for Studies in South Asian Perspectives (CGSSAP), Friedrich Ebert Stiftung, New Delhi.

4. World Bank Data Bases, various issues, IBRD, Washington/New York. 
